\title{
Gran Sabana fires (SE Venezuela): a paleoecological perspective
}

\author{
Encarni Montoya ${ }^{\mathrm{a}, \mathrm{b}}$, Valentí Rull \\ a Department of Animal Biology, Vegetal Biology and Ecology, Autonomous University of Barcelona, 08139 Bellaterra, \\ Barcelona, Spain \\ b Palynology and Paleoecology Lab, Botanic Institute of Barcelona (IBB-CSIC-ICUB), Ps del Migdia s/n, 08038 \\ Barcelona, Spain
}

\begin{abstract}
Fires are among the most important risks for tropical ecosystems in a future climatic change scenario. Recently, paleoecological research has been addressed to discern the role played by fire in neotropical landscapes. However, given the magnitude of the Neotropics, many studies are relegated to infer just local trends. Here we present the compilation of the paleo-fire records developed until now in the southern Gran Sabana (SE Venezuela) with the aim to describe the fire history as well as to infer the possible forcing factors implied. In this sense, southern Gran Sabana has been under fire perturbation since the Lateglacial, with the concomitant effects upon vegetation, and persisted during the Holocene. Around $2000 \mathrm{cal} \mathrm{yr} \mathrm{BP}$ onwards, the fire activity highly increased promoting the expansion of pre-existing savannas, the decrease of forests and the appearance and establishment of Mauritia palm swamps. The continuous fire incidence registered for several thousands of years has likely promoted the supremacy of treeless savannas upon other vegetation types and the degradation to secondary landscapes. Based on the available evidence, the anthropogenic nature of this high fire activity has been postulated. If so, it could be hypothesized that the timing arrival of Pemón, the present-day indigenous culture in the Gran Sabana, would be ca 2000 cal yr BP onwards, rather than the last centuries, as it has been formerly assumed. The implications of these ancient practices in the area are also discussed for present Gran Sabana landscapes sustainability and future conservation strategies.
\end{abstract}

Key words: Fires, Gran Sabana, Indigenous populations, Microcharcoal, Paleoecology, Palynology, Sustainability, Venezuela

Accepted by Elsevier 9 September 2011

\section{Introduction}

Fire is now recognized as a key factor in the Earth system, especially with respect to the global carbon cycle, atmospheric chemistry, and the regulation of terrestrial ecosystems and biodiversity (Power et al., 2008; Flannigan et al., 2009). The complexity of the relationships between the different forcing factors related to fire make understanding and predicting the behavior of fire a difficult task (Bowman et al., 2009), although some accurate work has been done (e.g.: Hoffmann et al., 2002). It is unquestioned that fire has played a significant role in determining present-day vegetation (Hoffmann et al., 2002; Bond et al., 2005). The effect of fire on global vegetation distribution and occurrence has been highlighted by Bond et al. (2005), 
showing that e.g., in the total absence of fire, closed forests would double from $27 \%$ to $56 \%$ of vegetated landscapes.

These observations of present-day vegetation patterns and extent are especially true for tropical savannas (Bond et al., 2005), where the environmental conditions (mainly climate and soil properties) are in many cases suitable for the development of forests in the absence of fire. The Tropics have been highlighted as the region where the most fires occur on Earth (Cochrane, 2009). Savanna fires have been considered the largest source of natural pyrogenic emissions, showing the most fire activity of all major land cover types (Pereira, 2003). Although there have been some attempts to use satellite imagery to study them, several attributes of tropical fires greatly complicate such work (Pereira, 2003). In the Colombian Llanos, Romero-Ruiz et al. (2010) studied the variability of fire incidence in this region during an interval of eight years. These authors observed a range of fire recurrency from $33.5 \%$ of the area that was never burned to $18 \%$ of the land that was burned more than four times. This high variability was mainly a result of differences in ecosystem type, land tenure, and rainfall, and it was observed that fires were more common in national parks and indigenous reserves than on ranches (Romero-Ruiz et al., 2010). For savannas from the State of Roraima, Brazil, a frequency of fire every 2.5 years in average was observed, with the major occurrence areas close to human settlements (Barbosa and Fearnside, 2005). That study also highlighted that between 70 and $80 \%$ of the burned areas did not register fire events the next year, but instead they were new fires produced in new zones, with the consequent impact on the ecosystem.

Paleoecological studies are undoubtedly an important tool for obtaining information about past fire records and to thus try to establish a fire regime, useful for future predictions and fire prevention, if necessary (Whitlock and Larsen, 2001; Whitlock et al., 2010). Based on paleo-records, it was observed that global fire incidence has been increasing since the Last Glacial Maximum (LGM; ca 21,000 cal yr BP) until the present (Power et al., 2008). This study also reflected the increase in spatial heterogeneity from $12,000 \mathrm{cal}$ yr BP onward, probably caused by regional climate control, although the human role should not be ruled out. This is the case of the Neotropics, where a huge increase in fire activity has been documented synchronous with human arrival, ca 12.5 cal kyr BP onwards (Haberle and Ledru, 2001). Although, globally, fire has been mostly driven by climate until recent times (Marlon et al., 2008), the situation in the Neotropics differs substantially due to the anthropogenic nature of most fire events (Shlisky et al., 2009). Some paleoecological studies have shown evidence of fires related to human populations in NE Amazonia since at least $8000 \mathrm{cal}$ yr BP (Hammond et al., 2006; Bush et al., 2007). Moreover, although there is a general lack of paleo-fire records in the Neotropics, several studies have revealed the presence of paleo-fires in northern South America during the Holocene, probably related to a climate (mainly El Niño Southern Oscillation intensification and solar insolation) and human impact synergism (Sanford et al.,1985; Hammond et al., 2006; Bush et al., 2008).

In this paper, we present a compilation of the most recent paleoecological studies, including fire records, conducted in a landscape that in the present-day is under high fire incidence: the southern Gran Sabana (a mid-altitude plateau located in SE Venezuela). This region is characterized by an extensive treeless savanna patch within tropical rain forests, located between the Orinoco and Amazon watersheds (See Section 2). Paleoecology in this area has revealed several climatic variations, fire presence, and vegetation changes since the Early Holocene (Rull, 1992, 1999, 2007). Thus, the general vegetation trend in the Gran Sabana is an increase of treeless savannas, a decline of forests, and the appearance and expansion of morichales (palm swamps of Mauritia flexuosa), which form the present landscape. The paleoecological 
analyses carried out suggested that climate and fires were the main forcing factors that favored the establishment of the present vegetation (Rull, 1992, 1999, 2007). Prior to the sequences reported here, only two records for Gran Sabana contain evidence of fire activity, the Mapaurí and Urué sequences (Rull, 1999, 2007, 2009a). The aim of the present work is focused on the reconstruction of the long-term Gran Sabana fire activity. The detailed paleoecological reconstructions based on pollen analysis of the sequences presented here have been published elsewhere (Montoya et al., 2009, $2011 a, b, c)$. Here, the emphasis is on fire history (based mainly on charcoal analysis), and the results are compared with previous fire records (namely Mapaurí and Urué sequences), with the aim of discerning a more regional overview of fire processes. This regional overview will be then used to analyze the long-term effects of fire in the southern Gran Sabana vegetation, as well as the history of human occupation and its role in landscape dynamics.

\section{The Gran Sabana}

The Gran Sabana (GS) is a region of about $18,000 \mathrm{~km} 2$ located in SE Venezuela, between the Orinoco and Amazon basins (4_360e6_370N and $61 \_40 \mathrm{e} 74$ _20W, (Fig. 1). Geomorphologically, the GS is an undulated erosion surface developed on Precambrian Roraima quartzites and sandstones, which forms an Altiplano slightly inclined to the south, ranging from about 750 to $1450 \mathrm{~m}$ elevation (Briceño and Schubert, 1990; Huber, 1995a). The climate has been described as submesothermic ombrophilous, with annual average temperatures of around $18 \mathrm{e} 22$ _C and precipitation values of $1600 \mathrm{e} 2000 \mathrm{~mm}$ yr_1, with a dry season ( $<60 \mathrm{~mm} / \mathrm{month})$ from December to March (Huber and Febres, 2000). With respect to vegetation, GS is a huge island of savanna within the normally forested Guayanan landscape. These savannas form wide, more or less continuous, treeless grasslands, but in some places they are intermingled with forests and shrublands, thus developing a typical forest-savanna mosaic (Huber, 1994a) (Fig. 2). The dominance of savanna vegetation in a climate apparently more suitable for the development of extensive rain forests (Huber, $1995 a, b)$ has lead to several hypotheses basically centered on either climatic factors or anthropogenic fires as possible causes (see: Eden, 1974; Fölster, 1986; Rull, 1999, 2007; Fölster et al., 2001; Dezzeo et al., 2004a; Huber, 2006).

There is a visual differentiation between northern and southern GS vegetation, where the present study is focused (Huber and Febres, 2000). While in the northern GS the presence of shrubs and forest patches is common, in the south the savanna extension increases, relegating forests mainly to water courses or mountain slopes. Also in the southern GS there exists a special vegetation type, absent in the northern region, locally called morichales (Huber, 1994b). The morichal is a palm swamp developed in a wide alluvial plain and dominated by the Arecaceae $\mathrm{M}$. flexuosa. This vegetation type is especially common in the bottom of river valleys and flooded depressions, and it has been suggested that the absence of these communities in the northern GS is due to an altitudinal boundary around $1000 \mathrm{~m}$ of distribution of this palm (Huber, 1994b, 1995b).

The GS region is presently the homeland of the Pemón indigenous group, from the Carib-speaking family. Today, they are sedentary, living in small villages, usually in open savannas. Though the GS population density is relatively low, the indigenous settlements have experienced an expansion since the arrival of modern day European missions, and today more than 17,000 people live in GS (Medina et al., 2004). The date of arrival of the Pemón people to GS is still unknown. Based mainly on historical documents, it has been postulated that this culture settled in GS around 300 years ago, coming from the East (fromthe Rupununi savannas of Guyana; Thomas, 1982; Colson, 
1985; Kingsbury, 1999), or around 500e600 years ago, migrating from the Rio Branco (Huber, 1995a). In either case, these accounts do not necessarily represent their first arrival, so an early human occupation by the Pemón or other cultures cannot be dismissed. Indeed, there is some archaeological evidence consisting of pre-Hispanic remains (spearheads and bifacial worked knives), similar in style to others about 9000 years old found in other Venezuelan localities (Gassón, 2002). Therefore, a definitive assessment is not yet possible.

Fire is a key component of the Pemón culture as they use it every day to burn vast areas of savannas, and occasionally forests (Kingsbury, 2001). The reasons for the extent and frequency of these fires include activities such as cooking, hunting, fire prevention, communication, magic, etc. (Rodríguez, 2004, 2007). Surprisingly, land use practices, such as extensive agriculture or cattle raising, typical of other cultures strongly linked to fire, are not characteristic of the Pemón culture (Rodríguez, 2004). The large number of fires today in GS (between 5000 and 10,000 fires per year (Gómez et al., 2000)) is essentially human-made, which has resulted in a debate related to the sustainability of the present landscape and the possible factors that led to its development (Rodríguez, 2004; Dezzeo et al., 2004b; Rull, 2009b). With respect to conservation issues, it seems logical to postulate that fire is a key factor to take into account, due to the intensive and extensive fires that currently occur. Since 1981, the government of the region (through the regional hydro-electric company, called EDELCA) has developed several actions focused mainly on fire suppression (EDELCA, 2004). However, the low effectiveness obtained (about $13 \%$ of fires are controlled and extinguished) has called the utility of these expensive measures into question (Sletto, 2008; Bilbao et al., 2010). This low success rate is mainly due to (i) the large extension of the area to monitor; (ii) the high number of daily fires; (iii) a bias in fire control measures focused only in specific locations; and (iv) the anthropogenic character of fires, which make any kind of prevention measures difficult (Rodríguez, 2007; Bilbao et al., 2010).

\section{Coring sites and methods}

The cores studied belong to the southern GS region. Two cores, Lake Chonita and the Lake Encantada peat bog, are located within the nowadays typical southern GS landscape of treeless savannas with morichales (frequently surrounding water courses or in flooded depressions; Fig. 2), whereas the third core (EI Paují peat bog) is located on the boundary between treeless GS savannas and Amazonian rain forests. These three localities are close to Santa Elena de Uairén at 910 m elevation (Fig. 1), with annual precipitation of about $1700 \mathrm{~mm}$, and a moderate dry season from December to March (Huber, 1995a).

\subsection{Lake Chonita (core PATAM1_B07)}

The study site (4_390Ne61_00W, $884 \mathrm{~m}$ elevation) is located within a private farm called "Hato Divina Pastora" (Fig. 1). The lake is within a treeless savanna landscape, surrounded by scattered morichal stands. The core studied (PATAM1 B07; $4.67 \mathrm{~m}$ long) was obtained in the deepest part of the lake (3.13 mwater depth), using a modified Livingstone squared-rod piston core (Wright et al., 1984). This record contains the last $15.3 \mathrm{cal} \mathrm{kyr}$ BP. The Lateglacial and last millennia vegetation history have already been published (Montoya et al., 2011a,b). For the Lateglacial section (from 2.97 to $4.67 \mathrm{~m})$, thirty-five volumetric samples $(2 \mathrm{~cm} 3)$ were taken for palynological 
analyses every $5 \mathrm{~cm}$. For the last millennia (from 0.03 to $0.97 \mathrm{~m}$ ), twenty-eight volumetric samples $(2 \mathrm{~cm} 3)$ were taken for palynological analyses every $2 \mathrm{e} 5 \mathrm{~cm}$.

\subsection{Lake Encantada (core PATAM4_D07)}

The study site (4_420Ne61_40W; $867 \mathrm{~m}$ elevation) is located within a private farm called "Hato Santa Teresa" (Fig. 1). The lake is surrounded by extended treeless savanna, which at the shores is transformed into a peat bog with some scattered $M$. flexuosa individuals. The sequence studied (PATAM4 D07; $3.92 \mathrm{~m}$ long) was extracted with a Russian core (Jowsey, 1966) from one of these peat bogs at the shore. This record accounts for the last 7500 cal years $\mathrm{BP}$, and the main vegetation trends, at a millennial timescale, are already available (Montoya et al., 2009). Twenty-five samples $(3 \mathrm{e} 4 \mathrm{~g})$ were taken for palynological analyses every $15 \mathrm{e} 20 \mathrm{~cm}$.

\subsection{El Paují (core PATAM5_A07)}

The last sequence of the present study (4_280Ne61_350W, $865 \mathrm{~m}$ elevation) is located near the El Paují indigenous community, in the most southern part of the GS region, and close to the Brazilian border (Fig. 1). The peat bog is situated on a slight slope and is near to different forest types. The peat bog is formed by Brocchinia (Bromeliaceae) and surrounded by Orectanthe and Xyris (Xyridaceae) as the main vegetation. The landscape is formed by an open herbaceous vegetation type on both sides of the road from Santa Elena to Icabarú within a forested zone. The core studied (PATAM5 A07; $2.19 \mathrm{~m}$ long) was obtained in the deepest part of the peat bog, using a Russian core (Jowsey, 1966). This core records the past $8250 \mathrm{cal}$ years BP, and the palynological study is already available (Montoya et al., 2011c). Forty-three samples (3e4 g) were taken for palynological analyses every $5 \mathrm{~cm}$. General palynological methods (e.g., pollen and spore guides used for identification, etc.) are described in detail by Montoya et al. (2009, 2011a,b,c); here a summary will be provided. Samples for radiocarbon dating were measured at the Keck Carbon Cycle AMS Lab at the University of California, Irvine, and Beta Analytic Inc.

Samples for pollen and microcharcoal analyses were processed using standard palynological techniques slightly modified according to the sediment characteristics (Rull et al., 2010) after spiking Lycopodium tablets (Lake Encantada: batch 124,961, average 12,542 _ 2081 spores per tablet; Lake Chonita and El Paují: batch 177,745, average 18,584_ 1853 spores per tablet). The slides were mounted in silicone oil without sealing. Diagrams were plotted with PSIMPOLL 4.26, using a timescale derived from an age-depth model based on radiocarbon dating, developed with the clam. $\mathrm{R}$ statistical package (Blaauw, 2010). The zonations were performed by Optimal Splitting by Information Content (OSIC), and the number of significant zones was determined by the broken-stick model test (Bennett, 1996). Interpretations of the reconstructed vegetation were based on comparison with modern samples from previous studies (Rull, 1992, 1999), and the known autoecology of taxa found (Marchant et al., 2002; Rull, 2003). Charcoal analyses were based on particles count divided in size classes defined and modified from Rull (1999), resulting three main groups:

- Type I: (smaller microcharcoal particles: $5 \mathrm{e} 100 \mathrm{~mm}$ ): used as proxy for mostly regional fires because of their easy dispersion by wind and/or water.

- Type II: (larger microcharcoal particles: >100 mm): used as proxy for local fires. 
- Type III: (largest microcharcoal particles: $>500 \mathrm{~mm}$ ): used as proxy for high virulence local fire events. Used only for peat bog sequences (Lake Encantada and Paují), and plotted as presence/absence data (Figs. 5 and $\underline{6}$ ).

Modern charcoal sedimentation studies have been recently developed in the GS (Leal, 2010). Although they have not been published yet, we have used some of their results in the interpretation of the sequences analyzed here.

\section{Results and interpretation}

\subsection{Vegetation history}

The main vegetation trends and inferred climate of the three sequences analyzed are provided and summarized in Fig. 3 together with other GS sequences studied so far.

\subsubsection{Lake Chonita (core PATAM1_B07)}

The results of the radiocarbon dating were used to produce an age-depth model for the whole sequence (See model in Supplementary Information: S1), being the best fit obtained with a smooth-spline model (Blaauw, 2010). According to this model, sedimentation rates ranged in the Lateglacial interval from 0.03 to $0.16 \mathrm{~cm} / \mathrm{yr}$ and in the last millennia from 0.02 to $0.08 \mathrm{~cm} / \mathrm{yr}$, which represents a mean resolution between samples of $30 \mathrm{e} 165$ and $60 \mathrm{e} 150$ years respectively.

The pollen diagram of the Lateglacial interval was subdivided into three zones according to variations in the pollen assemblages (Montoya et al., 2011a). The first zone (CHO-I: from 15.3 to 12.7 cal kyr BP) was barren, except for some isolated samples with scattered and mostly degraded palynomorphs. The sediment was characterized by gray clay with desiccation features. This zone probably represented a period of high clastic sedimentation and low plant cover, and the absence of biological proxies was interpreted as very dry climate (Fig. 3). The second zone (CHO-II: from 12.7 to $11.7 \mathrm{cal} \mathrm{kyr}$ BP) was characterized by a shrubland with no modern analogs dominated by Bonyunia, Miconia and Myrsine. The scarce presence of aquatic elements was interpreted as indicatives of dry climate (Fig. 3). CHO-III (from 11.7 to $10.6 \mathrm{cal}$ kyr BP) was characterized by a marked change in the pollen assemblage, which corresponds to a treeless savanna (Fig. 4). The occurrence of aquatic elements and the disappearance of the shrubland of the former zone were interpreted as wetter and warmer conditions (Fig. 3).

The last millennia section was characterized by the continuous presence of treeless savanna, but variations in the pollen assemblages allowed its subdivision intotwozones (Montoya et al., 2011b). The first zone ( $\mathrm{LCH}-\mathrm{I}$ : from 3.6 to $2.2 \mathrm{cal} \mathrm{kyr} \mathrm{BP}$ ) showed a landscape dominated byPoaceae, and the presence of nearby ormoreextended forests than today (Fig. 3). The effective moisturewas interpreted as higher than present prior to $2.8 \mathrm{cal}$ kyr BP. During LCH-II (from $2.2 \mathrm{cal}$ kyr BP to present), the vegetation was characterized by the sudden appearance and expansion of Mauritia, and the decline of the surrounding forests (Fig. 7). The effective moisture did not showany significant change after $2.8 \mathrm{cal} \mathrm{kyr} \mathrm{BP}$ (Figs. 3 and 7 ).

\subsubsection{Lake Encantada (core PATAM4_D07)}

Radiocarbon dates were used to produce an age-depth model (Supplementary Information: S2), being the best fit obtained with a linear interpolation model (Blaauw, 2010). According to this model, sedimentation rates ranged from 0.02 to $0.22 \mathrm{~cm} / \mathrm{yr}$, being the mean resolution between sampling intervals of 280 and 350 years. 
The pollen diagram of Lake Encantada showed the continuous presence of a treeless savanna as the dominant vegetation during the last 7500 years (Montoya et al., 2009). However, variations in the pollen assemblages allowed the subdivision of the diagraminto three zones. The first zone (SM-I: from 7.5 to 2.47 cal kyr BP) was marked by the presence of treeless savanna with nearby or more expanded forests than today, with a peak centered around 4.0 calkyr BP (Fig. 5). Synchronous with this maximum in forest taxa, an increase in aquatic elements was also recorded that was interpreted as indicative of wetter conditions (Fig. 3). In SM-II (from2.47 to 1.22 cal kyr BP) forest extent began to decrease whereas the first appearance of Mauritia was registered, though in low abundance (Fig. 5). The upper pollen zone (SM-III: from $1.22 \mathrm{cal} \mathrm{kyr} \mathrm{BP}$ to present) was marked by the abrupt expansion of Mauritia, and the decrease of forest until almost its disappearance. The aquatic elements suggested an effective moisture slightly lower than in former zones (Fig. 3 ).

\subsubsection{El Paují (core PATAM5_A07)}

Radiocarbon samples of El Paují were used to produce an age-depth model Supplementary Information: S3), being the best fit obtained with a smooth-spline model (Blaauw, 2010). According to this model, sedimentation rates ranged from 0.02 to 0.07 $\mathrm{cm} / \mathrm{yr}$, which represents around 160 years per sampling interval in average.

The pollen assemblages found in El Paují sequence showed several vegetation shifts between open (savanna/forest mosaics or savanna) and closed (forest) landscapes that allowed a subdivision into five zones (Montoya et al., 2011c). The first zone (PAUI: from 8.25 to $7.72 \mathrm{cal}$ kyr BP) was interpreted as an open landscape dominated by Poaceae and Urticales and an inferred drier climate than present (Figs. 3 and $\underline{6}$ ). The second zone (PAU-II: from 7.72 to $5.04 \mathrm{cal} \mathrm{kyr} \mathrm{BP)} \mathrm{was} \mathrm{characterized} \mathrm{by} \mathrm{an} \mathrm{increase} \mathrm{in}$ forests and similar effective moisture than in the former zone. In zone PAU-III (from 5.04 to $2.69 \mathrm{cal} \mathrm{kyr}$ BP) the pollen assemblage was interpreted as a savanna/forest mosaic and an increase in effective moisture (Fig. 3). During PAU-IV (from 2.69 to 1.44 cal kyr BP), the former rain forests continued to decrease, and the appearance of a new, likely secondary dry forest vegetation type dominated by Fabaceae and the decline of algae suggested drier conditions (Fig. 3). The upper zone (PAU-V: from 1.44 cal kyr BP to present) was characterized by the establishment of the current landscape (treeless savanna) during the wettest interval of the whole sequence (Fig. 3). Mauritia pollen was not found in this sequence and this palm is not present nowadays in the site (Montoya et al., 2011c).

\subsection{Fire history}

\subsubsection{Late-glacial/Early Holocene transition}

The Lateglacial record of Lake Chonita shows the presence of fires since the Younger Dryas (YD; 12.7e11.7 cal kyr BP). Smaller charcoal particles e interpreted as regional fire proxies e were present from the beginning of the zone, as well as psilate trilete spores, indicative of early successional stages after fire in GS (Rull, 1999), which showed a very pronounced increasing trend (Fig. 4). The increase in regional fires and the beginning of local fires (indicated by the presence of larger charcoal particles) coincided with a dramatic vegetation replacement, dated at the end of the zone (around $11.7 \mathrm{cal} \mathrm{kyr} \mathrm{BP}$ ), coinciding with the end of YD (Fig. 4). The frequency reached since the first evidence of fires remained until the top of the sequence, even when an increase in water level was recorded in the Early Holocene (Fig. 3). This increase in fire activity could have been caused by either climatic or anthropogenic factors, or both (Montoya et al., 2011a). 


\subsubsection{Holocene}

The two peat bog sequences (Lake Encantada and El Paují) reported the main trends of vegetation during the Holocene, spanning from $8 \mathrm{cal}$ kyr BP until the present-day. Both sequences are characterized by the presence of fires since the onset of the records. Local fires were registered at the beginning in low abundance. At Lake Encantada, regional fires were characterized by a continuous presence without marked changes prior to $2470 \mathrm{cal} \mathrm{yr} \mathrm{BP}$, excepting two peaks that differed in their vegetation response (Fig. 5). After the first fire peak, an increase in shrubs was recorded, whereas the second one did not correspond to any clear shift in vegetation. Regarding El Paují record, some variations in the charcoal curve were recorded in the lower part of the sequence that are worth mentioning (Fig. 6). For instance, around $7715 \mathrm{cal} \mathrm{yr} \mathrm{BP,} \mathrm{a}$ sudden increase in forest elements was recorded, synchronous with a peak in regional fires and a decline of Poaceae, probably the consequence of savanna fires (Figs. 3 and 6). From 5040 to $2690 \mathrm{cal} \mathrm{yr} \mathrm{BP,} \mathrm{the} \mathrm{location} \mathrm{was} \mathrm{marked} \mathrm{by} \mathrm{an} \mathrm{increasing} \mathrm{trend} \mathrm{in} \mathrm{fire}$ activity, which promoted a decrease in forest extension (ig. 6).

The beginning of the Late Holocene in these two sequences (Lake Encantada and El Paují) differed substantially. From 2470 to 1220 cal yr BP, Lake Encantada was marked by an increasing trend in regional and local fires with respect to the former zone (SM-I; Figs. 5 and 8), which ended with an abrupt peak in regional fires. The vegetation during this interval was characterized by a decrease in forest elements and the appearance of Mauritia, though in low abundances (Fig. 5). In the El Pauji sequence, however, the same interval (from 2690 to $1440 \mathrm{cal}$ yr BP) was characterized by a decline in the fire activity, both in regional and local fires (Figs. 6 and $\underline{8}$ ). The decline of fires was paralleled by a drop in the former existing rainforest (Urticalesdominated), which initiated a decreasing trend in the previous zone, and the rapid appearance of a secondary dry forest (Fabaceae-dominated), likely favored by the existence of dry climates (Fig. 3). The Late Holocene section of Lake Chonita has been studied in higher resolution elsewhere (Montoya et al., 2011b). Regional fires were present since the beginning of the interval analyzed ca $3.6 \mathrm{cal} \mathrm{kyr} \mathrm{BP}$ and were characterized by a slightly increasing trend, whereas local fires appeared around 2.2 cal kyr BP (Figs. 7 and $\underline{8}$ ).

\subsubsection{Last two millennia}

Fig. 8 summarize last three millennia charcoal records of the three sequences studied here. The last two millennia of the Lake Encantada and EI Pauji sequences showed the same trend and were characterized by a marked increase in charcoal values (Figs. 5 and $\underline{6}$ ). At Lake Encantada, there was a pronounced increase of Mauritia synchronous with the fire increase, which almost completely replaced the forest (Fig. 5). This landscape, a treeless savanna with morichales, has remained until the present-day. Also at El Paují, an abrupt increase in fire incidence can be noted, and this has been maintained until the present, which likely promoted the expansion of grasslands (Fig. 6). Therefore, the current landscape of Lake Encantada and El Paují was established around 1220 and $1440 \mathrm{cal}$ yr BP, respectively. With respect to Lake Chonita, the beginning of local fires (ca $2.2 \mathrm{cal} \mathrm{kyr} \mathrm{BP}$ ) was synchronous with a dramatic increase in regional fires and a vegetation shift. This sequence was characterized by savannas with nearby forests that were suddenly replaced by a savanna with morichales, the present-day landscape, once local fires started (Fig. 7).

\section{Discussion}

The present results show that southern GS has suffered high fire occurrence at least since the Late Pleistocene, and especially during the last two millennia (Fig. 8). The main effect of these fires, in some cases probably coupled with climatic variations and 
other factors like the edaphic conditions (Montoya et al., 2009), has been a continuous impoverishment of the landscape diversity. A comparison with other GS sequences containing fire activity will be made in this section (Fig. 3), and the implications these results have for different disciplines will be elucidated.

\subsection{Comparison with other GS fire records}

The time intervals analyzed in previous GS paleo-fire records span since the Early Holocene to the present in Mapaurí (Rull, 2007, 2009a), and the last two millennia in Urué (Rull, 1999).

In the Mapaurí sequence (Fig. 1), Rull (2007) observed an abrupt vegetation replacement from a cloud forest to the establishment of a treeless savanna during the Early Holocene (Fig. 3). The Mapaurí vegetation shift was recorded at the same time as the presence of regional fires (Fig. 9); Rull, 2009a). With regard to climatic conditions, it was postulated the migration of the former forest to higher altitudes due to an increase of 2e3 _C in average temperatures (Rull, 2007). In this way, along with Lake Chonita, the paleoecological studies of the two unique sequences containing Lateglacial/Early Holocene intervals have shown that the southern GS landscape was probably a mosaic between forests, shrubs, and savannas, without the current dominance of this last vegetation type. Climate seems to have been the main forcing factor involved in the observed changes, but fires, which locally appeared during this interval in Lake Chonita, possibly also played a role. In this sense, these two sequences shed some light to the debate regarding the origin of present GS landscape and the possible drivers involved in its current extension.

The Urué sequence (Fig. 1) was marked by a high fire incidence around $1.7 \mathrm{cal} \mathrm{kyr} \mathrm{BP}$ that triggered a secondary succession (Figs. 3 and 10). This event also promoted a significant forest reduction and the expansion of savannas with morichales (Fig. 10; Rull, 1999). In Mapaurí, Rull (2009a) also documented an increase in both regional and local fires in the upper part of the sequence that has been maintained until the present (Fig. 9). However, the lack of additional radiocarbon dates prevents accurate determination of the onset of the interval neither the onset of fires increase. Other sequences studied in GS (Divina Pastora and Santa Teresa, Fig. 1; Rull, 1992) also showed an abrupt appearance of morichales during the last millennia that were interpreted as result of mainly climatic conditions (Fig. 3). Unfortunately, these two records did not contain charcoal analysis, so the presence and influence of fires upon vegetation, if they existed, cannot be taken into account.

Altogether, the results obtained so far regarding the fire activity of GS suggest that forests were present in variable extension during the Early and Mid-Holocene, and changed their range according to mainly climatic conditions, fires, or a synergy between them. In the Late Holocene, however, forests showed a dramatic decrease in all sequences, likely as the result of the continuous and high fire activity. Given the evidence reported, all sequences studied containing the last millennia highlighted the important role of fire in shaping the modern-day landscape in GS, likely accompanied by climate-driven effects that played a minor role (Fig. 3 ). Moreover, this interval has been characterized in all records by an increase in treeless savannas and, except for the Mapaurí and El Paují sequences, the establishment of morichales. Both Poaceae (for savannas) and Mauritia (for morichales) have shown a significant correlation with charcoal data in GS sequences (Rull, 2009a; Montoya et al., 2011b). 


\subsection{Implications for human occupancy}

Charcoal records indicate a continuous and relatively high fire incidence during the last millennia under the different climatic conditions recorded, suggesting that humans and no climate were the main responsible for such fire regimes (Fig. 3); Montoya et al., $2009,2011 a, b, c)$. Even in favorable climatic conditions, the occurrence of wild fires potentially initiated by lightning or other occasional stochastic causes would be more randomly distributed in time, and likely present during the Holocene drier phases, which is not the case. Furthermore, dry climates could only favor the occurrence of fires but cannot ignite them, whereas humans can do both things as they use to do nowadays in the Gran Sabana. In paleoecological records of the Neotropics, it has been suggested that the occurrence of phases of continuous and high fire incidence can be interpreted as a proxy for human settlements even in the absence of other land use signals, such as cultivated plants (Bush et al., 2007; de Toledo and Bush, 2007). Moreover, recent GS studies about modern pollen depositional rates have highlighted the absence of cultivated plant signals in this region, including locations where agriculture was developing, so the direct human impact in pollen records can easily go unnoticed (Rull, 2007, 2009a; Leal, 2010). In this sense, the onset of fires in the Lake Chonita catchment around 12.4 cal kyr BP might be evidence of postglacial human occupation in the region. The oldest fire events recorded for northern South American lowlands are from Lake Curuça (Brazil), ca 12.9e12.5 cal kyr BP (Behling, 2001), and Lake Surucucho (Ecuador), dated around the Pleistocene/Holocene boundary (Colinvaux et al., 1997); hence, the Lake Chonita fire event recorded here around 12.4 cal kyr BP is among the oldest fire events registered so far in the region.

There are some archaeological studies that documented the presence of stone tools of unknown radiocarbon age in nearby locations (Tupuquen and Canaima, Fig. 1) that were interpreted as evidence of Early Holocene cultures, who probably lit fires in open savannas for hunting (Navarrete, 2008; Rostain, 2008; Heckenberger and Neves, 2009). The presence of savannas at Lake Chonita from 11.7 cal kyr BP onwards coeval with the occurrence of local fires supports this hypothesis.

On the other hand, the anthropogenic impact on GS can be clearly observed during the Late Holocene (Fig. 8). The present-day indigenous culture in GS (Pemón) is characterized by living in open grasslands landscapes, with fire being a daily present element (Fig. 2). It could be assumed therefore that a shift in the GS fire activity should be registered coeval with the arrival of this indigenous group, as the pronounced increase in fire of the last two millennia recorded in all sequences. This hypothesis is consistent with the lack of evidence of regional drier climates (Fig. 3; Montoya, 2011), which would favor fires. In this sense, whereas the proxies used in Lake Chonita did not document any significant change in effective moisture during the last 2800 years, the upper sections of El Pauji (PAU-V) and Lake Encantada (SM-III) suggested the wettest and driest intervals of the whole sequences respectively (Figs. 5 and $\underline{7}$ ). Another potential evidence of indigenous population would be the abrupt Mauritia appearance and establishment, which could be an indicator of human presence (Behling and Hooghiemstra, 2000). To date, this palm has often been related with awarm and wet climate in paleoecological interpretations (Rull, 1992; Behling and Hooghiemstra, 1999; Berrío et al., 2000). In GS, its pyrophilous nature has also been postulated due to the observed synchrony between fire increase and Mauritia appearance (Figs. 3 and $\underline{5}$ ) (Montoya et al., 2009, 2011b). However, the socioeconomical importance of this palm for indigenous cultures has not been sufficiently considered in the paleoecological literature. M. flexuosa is commonly known as moriche, buriti, or tree of life, among others (Haynes and McLaughlin, 2000). This last name is refers to the utility of the palm for many present-day indigenous cultures, who 
obtain not just food resources from it but also housing materials and materials for other relevant activities (Henderson et al., 1995; Gomez-Beloz, 2002). In some archaeological studies, it has also been proposed that ancient cultures used the palm intensively (e.g.: Heckenberger and Neves, 2009), as is the case on Marajó Island. The mystery of the Marajó culture lies in the uncertainty of how a highly complex culture with a large population could have survived in unfavorable environmental conditions (e.g.: very low agricultural potential). In that case, Meggers (2001) proposed that the sustainability of the Marajó culture was based on starch extraction from M. flexuosa, due to the similarities found between modernday artifacts from nearby cultures that use the palm with those obtained on the island. In GS, soils are also characterized by nutrient deficiencies and progressive degradation after fire, resulting in a low agricultural efficiency (Dezzeo et al., 2004a). Therefore, the simultaneous appearance of Mauritia and increase of fires in GS might be due to intentional planting or semidomestication of the palm for human use. In this sense, further studies should be focused on the nature of the relationship of Mauritia with fire that, theoretically, would be due to: (i) the production of some substances favoring the expansion of fire or preventing damages caused by it (pyrophyly); (ii) the anthropic selection of vegetation susceptible to fires depending on the human needs; (iii) the climatic selection of vegetation susceptible to fires, iv) the superficial nature of fires that may affect the roots of most forest trees but not those of Mauritia, which are normally flooded; or (v) a synergy between these factors.

Another potential signal of early human settlement in GS is provided at the El Paují record. The development of vegetation succession pattern, inferred climate and fire activity along the sequence pointed to human occupation at the location since the Early Holocene. The fire incidence sometimes appears contradictory with the inferred climate, increasing in wet intervals and decreasing during drier climate periods, bolstering the interpretation of humans as the main driver for this fire occurrence (Figs. $\underline{3}$ and $\underline{6}$ ). Additionally, it was postulated that the fire activity and vegetation shifts documented during PAU-IV (from 2690 to $1440 \mathrm{cal}$ yr BP; Fig. 6) were likely driven by a synchrony between land abandonment and dry climate (Montoya et al., 2011c).

This sequence is located near the current boundary between the Yanomami and Pemón groups andwas tentatively interpreted as the existence of two different cultures at the site: (1) the first one present until 2690 cal yr BP, characterized by living in forested areas, with burnings attributed mainly to shifting cultivation (Yanomamilike culture); and (2) the second one present in the area from 1440 cal yr BP onwards, marked by the intensive practice of fires without an active land use (e.g., shifting cultivation within forest), as the Pemón indigenous group does today (Montoya et al., 2011c).

Hence, GS appears to have been occupied at least since the Late Holocene, especially during the last two millennia by the Pemón (or a similar fire-prone) culture. For the first time in the region this assumption is based on empirical data, and the timing of arrival proposed is much earlier -around 1500 years- than previously thought (Thomas, 1982; Colson, 1985; Huber, 1995a). Despite the scarce knowledge regarding early human populations in the region, some archaeological studies carried out in neighboring areas would agree with this hypothesis. For instance, Heckenberger and Neves (2009) postulated a north-south migration to tropical uplands and lowlands of Carib-speaking cultures (like Pemón) around $2500 \mathrm{e} 2000 \mathrm{yr}$ BP. On the other hand, an increase in population density has been suggested ca AD 600 in Guianas, due to the arrival of new cultures coming from the Orinoco delta and the Apure-Orinoco confluence to the zone (Rostain, 2008). In this sense, the maintained high fire activity recorded in GS characteristic of the last millennia could be interpreted as permanent presence in the 
region. However, sporadic or intermittent human settlements could have existed before, given the evidence of earlier fire events (Rostain, 2008).

\subsection{Implication for conservation: landscape management and local vs. global protection figures}

Given the evidence discussed, the present-day southern GS likely reflects a landscape intensively fire-managed during the Holocene, and especially during the last two millennia, rather than being the result of the response to only natural environmental conditions. However, the human activities have not been homogeneous throughout the GS. The sequences obtained within GS savannas (Lakes Chonita and Encantada) were characterized by continuous fire incidence with minor variations, until the regime dramatically increased during last two millennia. At El Paují, the establishment of a secondary dry forest registered in PAU-IV highlights that, although fire appears to be determinant regarding the establishment of current GS landscapes, the succession processes have likely been driven through time by a synergism between several factors. Besides climate, which also appeared as a main forcing factor in the general paleoecological analyses (Montoya et al., 2009, 2011a,b,c), the previously mentioned GS edaphic conditions were also probably involved (Fölster and Dezzeo, 1994; Dezzeo et al., 2004a). In this sense, Dezzeo and Chacón (2005) documented the progressive degradation of GS soils after fire, which could influence the ecological succession. Other evidence of the importance of edaphic conditions is the absence of morichales in Mapaurí and El Paují records. This absence could be also due to the lack of some soil or landscape features required by this vegetation type (such as the presence of permanent water-saturated soils or the existence of open landscapes, in terms of available free space, for the palm establishment). Therefore, it can be postulated that the current landscape of the southern GS is the result of the interplay between climate, edaphic conditions and anthropic management.

Currently, a high fire incidence is maintained, so taking into account the paleoecological information provided, the already existing conservation polices carried out in GS deserve special attention. In addition to the already mentioned regional conservation strategies performed by the hydro-electric company for its own interests, GS is located within the Canaima National Park, a UNESCO Biosphere Reserve and World Heritage Site (Huber, 1995c; http://whc.unesco.org/en/list/701). However, EDELCA strategies are focused only where potential economically profitable locations (gallery forests close to main river courses exploited by the company) can be under fire risk. This policy is therefore a reflection of the company economic interests rather than a conservation strategy for the region itself. Overall, the lack of connection between local practices and broader-scale conservation issues reveals a likely incoherence (Rull, 2009a). Here, two main aspects come to light: 1) the contradiction of allowing a high fire use in a protected region that has showed a large history of fire perturbation and concomitant vegetation responses, even more so when this high fire incidence is not produced currently for indigenous economical land uses (like agricultural or cattle raising lifestyle); and 2) the futility of global conservation policies without the agreement of local inhabitants.

A key point that should also be taken into account to acquire a more accurate view of the problem (and possible solutions) is the current relationship between indigenous and non-indigenous people in the region. Several authors have documented that fire use carried out by some indigenous cultures differs substantially depending on their remoteness with non-indigenous people and fire-fighter relationships, which primarily are reflected in cultural practices (Nepstad et al., 2006; Rodríguez, 2007; Sletto, 2009). 
The assistance provided by missions, the change from nomadic to sedentary communities, and the uncontrolled growth of communities, have altered the life-style of the Pemón and have promoted the unsustainability of ancient practices (Kingsbury, 2001, 2003; Dezzeo et al., 2004b). Moreover, the presence of fire-fighters in the region is perceived by the Pemón as a threat to their culture and therefore is not well received. In some Pemón sectors, fire use has changed sometimes to a habit rather than maintaining a specific purpose. In this sense, it has even been declared by some Pemón that one of the reasons for burning savannas is to irritate EDELCA and make the fire-fighters "work and get wet" (Rodríguez, 2007). It appears obvious that these practices are extremely harmful for GS ecosystems and by extension for GS inhabitants, even more if their survival as an indigenous culture is partially based on natural resources (namely from the forest). Undoubtedly, to succeed, future conservation strategies in GS should improve in terms of communication and positive interaction with the local population and monitoring (also from extra-local authorities) the compliance with established regulations.

To summarize, the southern GS vegetation trends and fire activity have revealed several shifts regarding climatic and anthropogenic factors. The present results highlight: (1) the importance of long-term studies for present and future management and conservation strategies (Vegas-Vilarrúbia et al., 2011); and (2) the complex relationship between all forcing factors implicated in shaping the current GS landscape. However, these observed landscape patterns should not be interpreted as tendencies for the whole region. New studies should be aimed to improve the knowledge about past and present-day GS landscape dynamics, as well as for future sustainability under climate change scenarios. Paleoecological approaches based on new complementary proxies such as macrocharcoal analysis (oriented to establish high resolution local fire regimes), or expanding the study area and/or nearby locations (e.g.: developing more studies, especially in northern GS where until recently there was research conducted; see Leal, 2010) are highly recommended, as well as the usefulness of multidisciplinary research.

\section{Conclusions}

The paleo-fire records developed until now in the southern GS have been interpreted together to obtain a regional view of the fire activity of the study area. Fire occurrence has been observed since the Lateglacial and throughout the Holocene. During the Late Holocene, around the last two millennia onwards the fire incidence abruptly increased in all sequences analyzed, and this high frequency has been maintained through to the present. The recorded fire activity in the area suggests that the present-day southern GS landscape is the result of a land highly managed and altered by humans, rather than a product just of climate variations. The evidence presented here supports the hypothesis of early human presence since the postglacial period in the region and surroundings. The anthropogenic impact in southern GS through fire use has likely promoted the expansion of savannas, the decline of forests and shrublands, and the appearance of morichales. Contrary to savannas, which existed prior to increasing fire incidence, the Mauritia stands were completely absent in the zone and appeared synchronously with the increase in fires recorded during the last millennia. This synchrony between Mauritia and fires around $2000 \mathrm{cal}$ yr BP may be indicative of the arrival of the Pemón to GS. This is supported by the high fire activity during this period to the present and by the intense use of this palm by humans, especially in areas with unfavorable soils for agriculture, like GS. Other evidence of pre-Columbian settlements was found in the El Pauji record, where the presence of two cultures with different fire and land uses is postulated. All the records showed that the present-day southern GS landscape might result from a secondary succession after fire. For this reason, it has 
been proposed that the fire prevention strategies currently developed in GS are necessary but insufficient, and they should be supplemented with positive interactions with local inhabitants, as well as extra-local agency monitoring tools

\section{Acknowledgments}

This work was supported by Spanish Ministry of Science and Innovation (former Ministry of Education and Science), projects CGL2006-00974 and CGL200907069/BOS to V. Rull, and grant BES-2007-16308 to E. Montoya. Permits to develop the research in Venezuela were provided by the Ministry of Science and Technology (DM/0000013, 5 Jan 2007), and sampling permits were provided by the Ministry of Environment (no IE-085, 9 Feb 2007). Thanks to Ana Ma Pérez, because of her huge effort to obtain them; to Fidencio Montáñez, owner of Hato Divina Pastora, El Paují indigenous community, and Aquiles and Jose Luis Fernández, owners of Hato Santa Teresa, for their interest and good willingness for our work; to Maarten Blaauw for his help with the age-depth modelling; to Iñigo de la Cerda for his support in the project; and to Jose S. Carrión for the use of his lab for pollen processing.

\section{Appendix. Supplementary material}

Supplementary material associated with this article can be found, in the online version, at http://dx.doi.org/10.1016/j.quascirev.2011.09.005

\section{References}

Barbosa, R.I., Fearnside, P.M., 2005. Fire frequency and area burned in the Roraima savannas of Brazilian Amazonia. Forest Ecology and Management 204, 371384.

Behling, H., 2001. Late Quaternary environmental changes in the Lagoada Curuça region (eastern Amazonia, Brazil) and evidence of Podocarpus in the Amazon lowland. Vegetation History and Archaeobotany 10, 175-183.

Behling, H., Hooghiemstra, H., 1999. Environmental history of the Colombian savannas of the Llanos Orientales since the last Glacial maximum from lake records el Pinal and Carimagua. Journal of Paleolimnology 21, 461-476.

Behling, H., Hooghiemstra, H., 2000. Holocene Amazon rainforest-savanna dynamics and climatic implications: high-resolution pollen record from Laguna Loma Linda in eastern Colombia. Journal of Quaternary Science 15, 687-695.

Bennett, K.D., 1996. Determination of the number of zones in a biostratigraphical sequence. The New Phytologist 132, 155-170.

Berrío, J.C., Hooghiemstra, H., Behling, H., van der Borg, K., 2000. Late Holocene history of savanna gallery forest from Carimagua area, Colombia. Review of Palaeobotany and Palynology 111, 295-308.

Bilbao, B., Leal, A.V., Méndez, C.L., 2010. Indigenous use of fire and forest loss in Canaima National Park, Venezuela. Assessment of and tools for alternative strategies of fire management in Pemón indigenous lands. Human Ecology 38, 663-673. 
Blaauw, M., 2010. Methods and code for 'classical' age-modelling of radiocarbon sequences. Quaternary Geochronology 5, 512-518.

Bond, W.J., Woodward, F.I., Midgley, G.F., 2005. The global distribution of ecosystems in a world without fire. New Phytologist 165, 525-538.

Bowman, D.J.S., Balch, J.K., Artaxo, P., Bond, W.J., Carlson, J.M., Cochrane, M.A., D'Antonio, C.M., DeFries, R.S., Doyle, J.C., Harrison, S.P., Johnston, F.H., Keeley, J.E., Krawchuk, M.A., Kull, C.A., Marston, J.B., Moritz, M.A., Prentice, I.C., Roos, C.I., Scott, A.C., Swetnam, T.W., van der Werf, G.R., Pyne, S.J., 2009. Fire in the earth system. Science 324, 481-484.

Briceño, H.O., Schubert, C., 1990. Geomorphology of the Gran Sabana, Guayana Shield. Geomorphology 3, 125-141.

Bush, M.B., Silman, M.R., de Toledo, M.B., Listopad, C., Gosling,W.D., Williams, C., De Oliveira, P.E., Krisel, C., 2007. Holocene fire and occupation in Amazonia: records from two lake districts. Philosophical Transactions of the Royal Society B: Biological Sciences 362, 209-218.

Bush, M.B., Silman, M.R., McMichael, C., Saatchi, S., 2008. Fire, climate change and biodiversity in Amazonia: a Late_Holocene perspective. Philosophical Transactions of the Royal Society B: Biological Sciences 363, 1795-1802.

Cochrane, M.A., 2009. Fire in the tropics. In: Cochrane, M.A. (Ed.), Tropical Fire Ecology. Praxis Publishing Ltd, Chichester (UK), pp. 1-24.

Colinvaux, P.A., Bush, M.B., Steinitz-Kannan, M., Miller, M.C., 1997. Glacial and postglacial pollen records from the Ecuadorian Andes and Amazon. Quaternary Research 48, 69-78.

Colson, A.B., 1985. Routes of knowledge, an aspect of regional integration in the circum-Roraima area of the Guayana highlands. Antropológica 63/64, 103-149.

de Toledo, M.B., Bush, M.B., 2007. A Mid-Holocene environmental change in Amazonian savannas. Journal of Biogeography 34, 1313-1326.

Dezzeo, N., Chacón, N., 2005. Carbon and nutrients loos in aboveground biomass along a fire induced forest-savanna gradient in the Gran Sabana, southern Venezuela. Forest Ecology and Management 209, 343-352.

Dezzeo, N., Chacón, N., Sanoja, E., Picón, G., 2004a. Changes in soil properties and vegetation characteristics along a forest-savanna gradient in southern Venezuela. Forest Ecology and Management 200, 183-193.

Dezzeo, N., Fölster, H., Hernández, L., 2004b. El fuego en la Gran Sabana. Interciencia 29, 409-410.

EDELCA, 2004. La cuenca del río Caroní. Una visión en cifras. CVG-EDELCA, Puerto Ordaz, Venezuela.

Eden, M.J., 1974. Paleoclimatic influences and the development of savanna in southern Venezuela. Journal of Biogeography 1, 95-109.

Flannigan, M.D., Krawchuk, M.A., de Groot, W.J., Wotton, B.M., Gowman, L.M., 2009. 
Implications of changing climate for global wildland fire. International Journal of Wildland Fire 18, 483-507.

Fölster, H., 1986. Forest-savanna dynamics and desertification processes in the Gran Sabana. Interciencia 11, 311-316.

Fölster, H., Dezzeo, N., 1994. La degradación de la vegetación. In: Dezzeo, N. (Ed.), Ecología de la Altiplanicie de la Gran Sabana (Guayana Venezolana) I. Investigaciones sobre la dinámica bosque-sabana en el sector SE: subcuencas de los ríos Yuruaní, Arabopó y Alto Kukenán. Scientia Guayanae, vol. 4. Ediciones Tamandúa, Caracas, pp. 145-186.

Fölster, H., Dezzeo, N., Priess, J.A., 2001. Soil-vegetation relationship in basedeficient premontane moist forest-savanna mosaics of the Venezuelan Guayana. Geoderma 104, 95-113.

Gassón, R.A., 2002. Orinoquia: the archaeology of the Orinoco River Basin. Journal of World Prehistory 16, 237-311.

Gómez, E., Picón, G., Bilbao, B., 2000. Los incendios forestales en Iberoamérica. Caso Venezuela. In: Vélez-Muñoz, R. (Ed.), La defensa contra incendios forestales. Fundamentos y experiencias. McGraw-Hill, Madrid.

Gomez-Beloz, A., 2002. Plant use knowledge of the Winikina Warao: the case for questionnaires in Ethnobotany. Economic Botany 56, 231-241.

Haberle, S.G., Ledru, M.P., 2001. Correlations among charcoal records of fires from the past 16,000 years in Indonesia, Papua New Guinea, and central and South America. Quaternary Research 55, 97-104.

Hammond, D.S., ter Steege, H., van der Borg, K., 2006. Upland soil charcoal in the wet tropical forests of central Guyana. Biotropica 39, 153-160.

Haynes, J., McLaughlin, J., 2000. Edible Palms and Their Uses. University of Florida. Institute of Food and Agricultural Sciences.

Heckenberger, M., Neves, E.G., 2009. Amazonian archaeology. Annual Review of Anthropology 38, 251-266.

Henderson, A., Galeano, G., Bernal, R., 1995. Field Guide to the Palms of the Americas. Princeton University Press, New Jersey.

Hoffmann, W.A., Schroeder, W., Jackson, R.B., 2002. Positive feedbacks of fire, climate, and vegetation and the conversion of tropical savanna. Geophysical Research Letters 29, 2052.

Huber, O., 1994a. La vegetación: arbustales. In: Dezzeo, N. (Ed.), Ecología de la Altiplanicie de la Gran Sabana (Guayana Venezolana) I. Investigaciones sobre la dinámica bosque-sabana en el sector SE: subcuencas de los ríos Yuruaní, Arabopó y Alto Kukenán. Scientia Guayanae, vol. 4. Ediciones Tamandúa, Caracas, pp. 95-106.

Huber, O., 1994b. La vegetación: Sabanas y herbazales de la Gran Sabana. In: Dezzeo, N. (Ed.), Ecología de la Altiplanicie de la Gran Sabana (Guayana Venezolana) I. Investigaciones sobre la dinámica bosque-sabana en el sector 
SE: subcuencas de los ríos Yuruaní, Arabopó y Alto Kukenán. Scientia Guayanae, vol. 4. Ediciones Tamandúa, Caracas, pp. 106-114.

Huber, O., 1995a. Geographical and physical features. Introduction. In:

Steyermark, J.A., Berry, P.E., Holst, B.K. (Eds.), Flora of the Venezuelan

Guayana, Vol. 1. Missouri Botanical Garden Press, Missouri, pp. 1-62.

Huber, O., 1995b. Vegetation. In: Steyermark, J.A., Berry, P.E., Holst, B.K. (Eds.), Flora of the Venezuelan Guayana (Vol. 1 Introduction). Missouri Botanical Garden Press, Missouri, pp. 97-160.

Huber, O., 1995c. Conservation of the Venezuelan Guayana. Introduction. In: Steyermark, J.A., Berry, P.E., Holst, B.K. (Eds.), Flora of the Venezuelan Guayana, vol. 1. Missouri Botanical Garden Press, Missouri, pp. 193-218.

Huber, O., 2006. Herbaceous ecosystems on the Guayana Shield, a regional overview. Journal of Biogeography 33, 464-475.

Huber, O., Febres, G., 2000. Guía ecológica de la Gran Sabana. The Nature Conservancy, Caracas.

Jowsey, P.C., 1966. An improved peat sampler. New Phytologist 65, 245-248.

Kingsbury, N.D., 1999. Increasing pressure on decreasing resources: a case study of Pemón Amerindian shfting cultivation in the Gran Sabana, Venezuela. Ph.D. thesis, York University, Canada.

Kingsbury, N.D., 2001. Impacts of land use and cultural change in a fragile environment: indigenous acculturation and deforestation in Kavanayén, Gran Sabana, Venezuela. Interciencia 26, 327-336.

Kingsbury, N.D., 2003. Same forest, different countries: cultural dimensions of protected area management in southeastern Venezuela and western Guyana. Journal of Sustainable Forestry 17, 171-188.

Leal, A.V., 2010. Historia holocena de la vegetación y el fuego en bordes sabana/ bosque y turberas de la Gran Sabana, Guayana Venezolana. Ph.D. thesis, Simón Bolívar University, Venezuela.

Marchant, R., Almeida, L., Behling, H., Berrío, J.C., Bush, M., Cleef, A., Duivenvoorden, J., Kappelle, M., De Oliveira, P., Teixeira, A., Lozano, S., Hooghiemstra, H., Ledru, M.P., Ludlow-Wiechers, B., Markgraf, V., Mancini, V., Páez, M., Prieto, A., Rangel, O., Salgado-Labouriau, M.L., 2002. Distribution and ecology of parent taxa of pollen lodged within the Latin American Pollen Database. Review of Palaeobotany and Palynology 121, 1-75.

Marlon, J.R., Bartlein, P.J., Carcaillet, C., Gavin, D.G., Harrison, S.P., Higuera, P.E., Joos, F., Power, M.J., Prentice, I.C., 2008. Climate and human influences on global biomass burning over the past two millennia. Nature Geoscience 1, 697702.

Medina, J., Croes, G., Piña, I., 2004. Evaluación de políticas públicas del pueblo Pemón: componentes socioeconómico y ambiental. D.d.A.I. Ministerio de Educación y Deportes. The Nature Conservancy, Caracas. 
Meggers, B.J., 2001. The mystery of the Marajoara: an ecological solution. Amazoniana 16, 421-440.

Montoya, E., 2011. Paleoecology of the southern Gran sabana (SE Venezuela) since the Late Glacial to the present. Ph.D. thesis, Autonomous Univ. Barcelona, Spain.

Montoya, E., Rull, V., Nogué, S., Díaz, W.A., 2009. Paleoecología del Holoceno en la Gran Sabana, SE Venezuela: análisis preliminar de polen y microcarbones en la Laguna Encantada. Collectanea Botanica 28, 75-89.

Montoya, E., Rull, V., Stansell, N.D., Bird, B.W., Nogué, S., Vegas-Vilarrúbia, T., Abbott, M.B., Díaz, W.A., 2011a. Vegetation changes in the neotropical Gran sabana (Venezuela) around the Younger Dryas Chron. Journal of Quaternary Science 26, 207-218.

Montoya, E., Rull, V., Stansell, N.D., Abbott, M.B., Nogué, S., Bird, B.W., Díaz, W.A., 2011b. Forest-savanna-morichal dynamics in relation to fire and human occupation in the southern Gran Sabana (SE Venezuela) during the last millennia. Quaternary Research. http://dx.doi.org/10.1016/i.yqres.2011.06.014.

Montoya, E., Rull, V., Nogué, 2011c. Early human occupation and land use changes near the boundary of the Orinoco and the Amazon basins (SE Venezuela): palynological evidence from El Paují record. Palaeogeography, Palaeoclimatology, Palaeoecology. http://dx.doi.org/10.1016/j.palaeo.2011.08.002.

Navarrete, R., 2008. The prehistory of Venezuela-not necessarily an intermediate area. In: Silverman, H., Isbell, W.H. (Eds.), Handbook of South American Archaeology. Springer, New York, pp. 429-458.

Nepstad, D., Schwartzman, S., Bamberger, B., Santilli, M., Ray, D., Schlesinger, P., Leferbvre, P., Alencar, A., Prinz, E., Fiske, G., Rolla, A., 2006. Inhibition of Amazon deforestation and fire by parks and indigenous lands. Conservation Biology 20, 65-73.

Pereira, J.M.C., 2003. Remote sensing of burned areas in tropical savannas. International Journal of Wildland Fire 12, 259-270.

Power, M.J., Marlon, J., Ortiz, N., Bartlein, P.J., Harrison, S.P., Mayle, F.E., Ballouche, A., Bradshaw, R.H.W., Carcaillet, C., Cordova, C., Mooney, S., Moreno, P.I., Prentice, I.C., Thonicke, K., Tinner, W., Whitlock, C., Zhang, Y., Zhao, Y., Ali, A.A., Anderson, R.S., Beer, R., Behling, H., Briles, C., Brown, K.J., Brunelle, A., Bush, M., Camill, P., Chu, G.Q., Clark, J., Colombaroli, D., Connor, S., Daniau, A.-L., Daniels, M., Dodson, J., Doughty, E., Edwards, M.E., Finsinger, W., Foster, D., Frechette, J., Gaillard, M.J., Gavin, D.G., Gobet, E., Haberle, S., Hallet, D.J., Higuera, P., Hope, G., Horn, S., Inoue, J., Kaltenrieder, P., Kennedy, L., Kong, Z.C., Larsen, C., Long, C.J., Lynch, J., Lynch, E.A., McGlone, M., Meeks, S., Mensing, S., Meyer, G., Minckley, T., Mohr, J., Nelson, D.M., New, J., Newnham, R., Noti, R., Oswald, W., Pierce, J., Richard, P.J.H., Rowe, C., Sanchez, M.F., Shuman, B.N., Takahara, H., Toney, J., Turney, C., Urrego-Sanchez, D.H., Umbanhowar, C., Vandergoes, M., Vanniere, B., Vescovi, E., Walsh, M., Wang, X., Williams, N., Wilmshurst, J., Zhang, J.H., 2008. Changes in fire regimes since the Last Glacial Maximum: an 
assessment based on a global synthesis and analysis of charcoal data. Climate Dynamics 30, 887-907.

Rodríguez, I., 2004. Conocimiento indígena vs científico: el conflicto por el uso del fuego en el Parque Nacional de Canaima, Venezuela. Interciencia 29, 121-129.

Rodríguez, I., 2007. Pemon Perspectives of fire management in Canaima national park, southeastern Venezuela. Human Ecology 35, 331-343.

Romero-Ruiz, M., Etter, A., Sarmiento, A., Tansey, K., 2010. Spatial and temporal variability of fires in relation to ecosystems, land tenure and rainfall in savannas of northern South America. Global Change Biology 16, 2013-2023.

Rostain, S., 2008. The archaeology of the Guianas: an overview. In: Silverman, H., Isbell, W.H. (Eds.), Handbook of South American Archaeology. Springer, New York, pp. 279-302.

Rull, V., 1992. Successional patterns of the Gran Sabana (southeastern Venezuela) vegetation during the last 5000 years, and its responses to climatic fluctuations and fire. Journal of Biogeography 19, 329-338.

Rull, V., 1999. A palynological record of a secondary succession after fire in the Gran Sabana, Venezuela. Journal of Quaternary Science 14, 137-152.

Rull, V., 2003. An illustrated key for the identification of pollen from Pantepui and the Gran Sabana (eastern Venezuelan Guayana). Palynology 27, 95-129.

Rull, V., 2007. Holocene global warming and the origin of the neotropical Gran sabana in the Venezuelan Guayana. Journal of Biogeography 34, 279-288.

Rull, V., 2009a. New paleoecological evidence for the potential role of fire in the Gran Sabana, Venezuelan Guayana, and implications for early human occupation. Vegetation History and Archaeobotany 18, 219-224.

Rull, V., 2009b. On the use of paleoecological evidence to Assess the role of humans in the origin of the Gran sabana (Venezuela). Human Ecology 37, 783-785.

Rull, V., Stansell, N.D., Montoya, E., Bezada, M., Abbott, M.B., 2010. Palynological signal of the Younger Dryas in the tropical Venezuelan Andes. Quaternary Science Reviews 29, 3045-3056.

Sanford, R.L., Saldarriaga, J., Clark, K.E., Uhl, C., Herrera, R., 1985. Amazon rainforest fires. Science 227, 53-55.

Shlisky, A., Alencar, A., Manta, M., Curran, L.M., 2009. Overview: global fire regime conditions, threats, and opportunities for fire management in the tropics. In: Cochrane, M.A. (Ed.), Tropical Fire Ecology: Climate Change, Land Use and Ecosystem Dynamics. Praxis Publishing Ltd, Chichester, pp. 65-83.

Sletto, B., 2008. The knowledge that counts: institutional identities, police science, and the conflict over fire management in the Gran Sabana, Venezuela. World Development 36, 1938-1955.

Sletto, B., 2009. Indigenous people don't have boundaries: reborderings, fire 
management, and productions of authenticities in indigenous landscapes. Cultural Geographies 16, 253-277.

Thomas, D.J., 1982. Order Without Government: The Society of the Pemons Indians of Venezuela. University of Illinois Press, Illinois.

Vegas-Vilarrúbia, T., Rull, V., Montoya, E., Safont, E., 2011. Quaternary palaeoecology and nature conservation: a general review with some examples from the Neotropics. Quaternary Science Reviews 30, 2361-2388.

Whitlock, C., Larsen, C., 2001. Charcoal as afire proxy. In: Smol, J.P., Birks, H.J.B., Last, W.M. (Eds.), Tracking Environmental Change Using Lake Sediments. Terrestrial, Algal, and Siliceous Indicators, vol. 3. Kluwer, Dordrecht, pp. 75-98.

Whitlock, C., Higuera, P.E., McWethy, D.B., Briles, C.E., 2010. Paleoecological perspectives on fire ecology: revisiting the fire-regime concept. The Open Ecology Journal 3, 6-23.

Wright, H.E., Mann, D.H., Glaser, P.H., 1984. Piston corers for peat and lake sediments. Ecology 65, 657-659. 


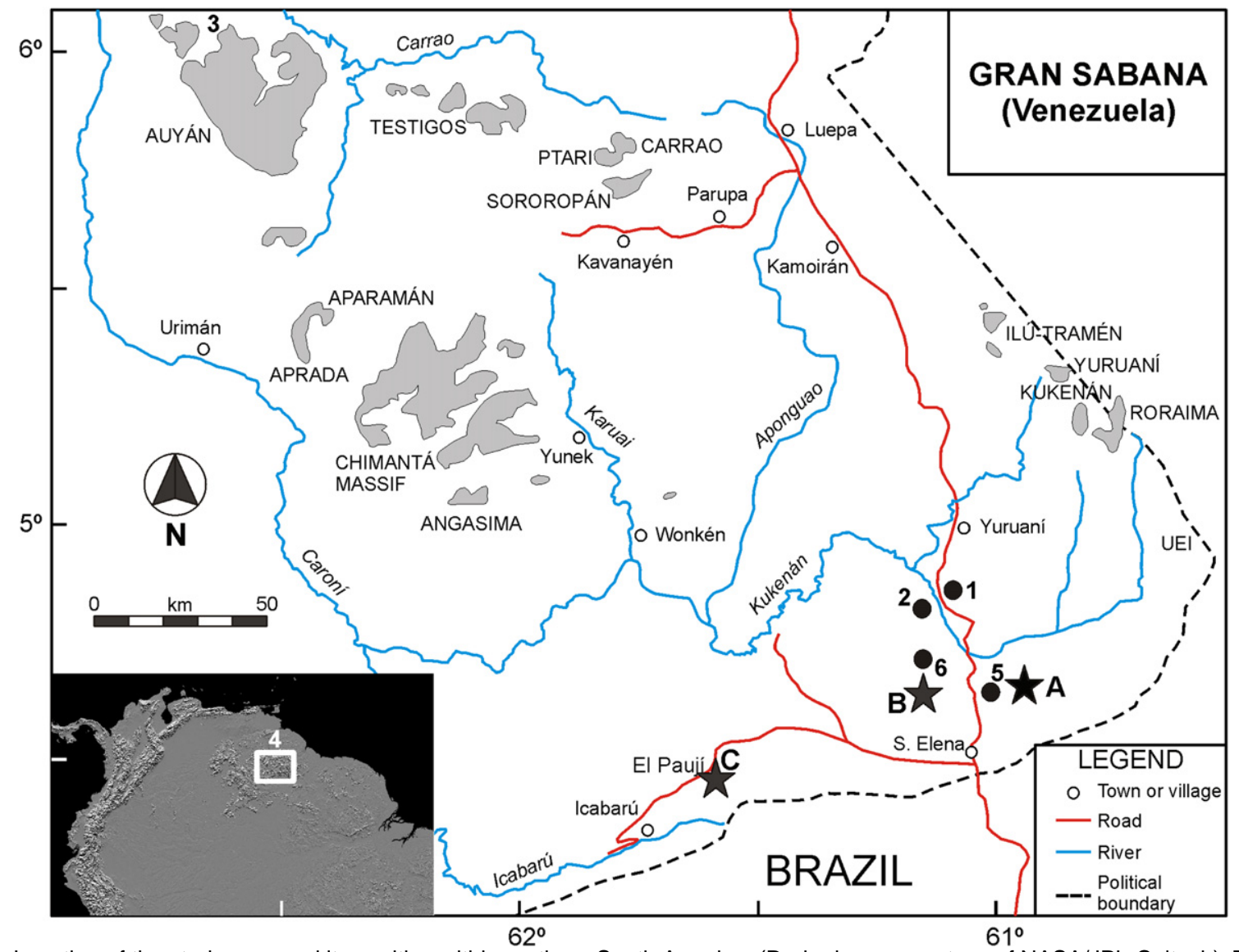

Fig. 1. Location of the study area and its position within northern South America. (Radar image courtesy of NASA/JPL-Caltech). The coring sites are indicated by stars and named with letters: AeLake Chonita (PATAM1_B07); BeLake Encantada (PATAM4_D07); and CeEl Paují (PATAM5A 07). Black dots indicate the locations of other Gran Sabana sequences mentioned in the text. Numbers indicate the sites with paleoecological information mentioned in the text: 1eMapaurí (Gran Sabana); 2eUrué (Gran Sabana); 3eCanaima (Venezuela); 4eTupuquen (Venezuela); 5eDivina Pastora (Gran Sabana), and 6eSanta Teresa (Gran Sabana). Gray zones: tepuian summits.

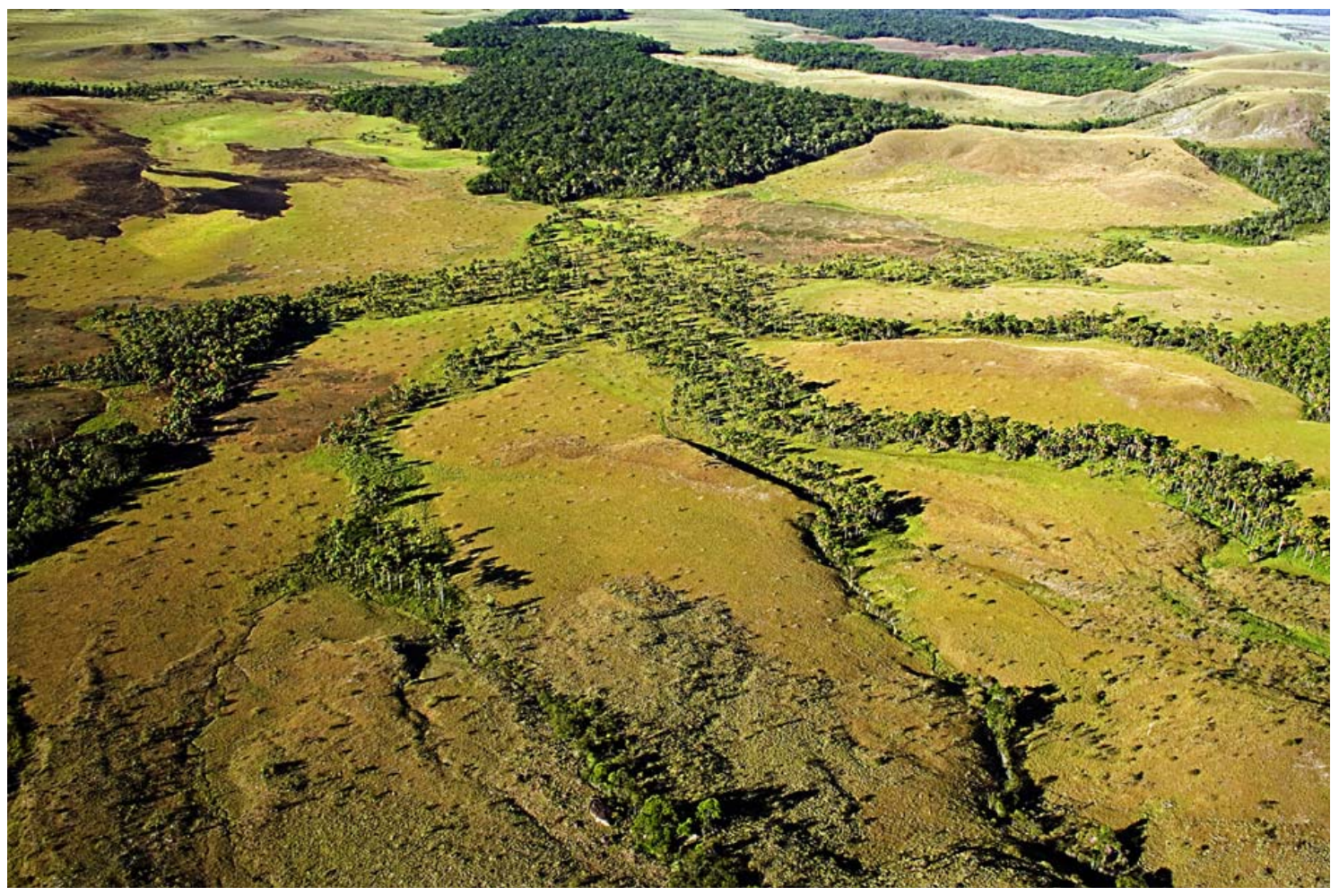

Fig. 2. Characteristic southern Gran Sabana landscape, with a retracting forest stand (background) surrounded by treeless savannas, and morichales (Mauritia palm swamps) expanding their range along rivers. Dark to light brown areas indicate the occurrence of recent or former anthropic fires. (Author: V. Rull). (For interpretation of the references to color in this figure legend, the reader is referred to the web version of this article.) 


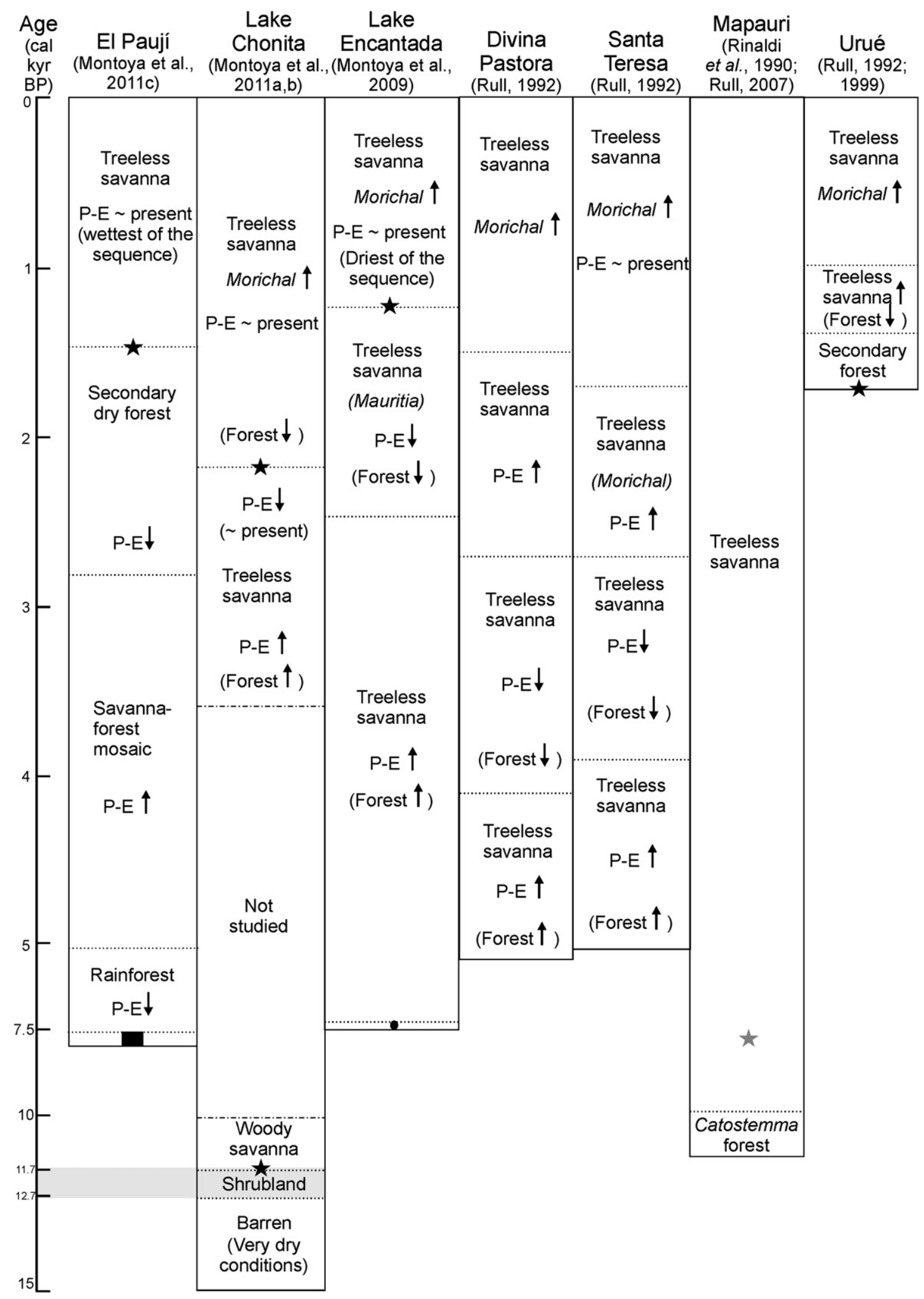

Fig. 3. Summary of paleoecological interpretations in the GS sequences studied to date. Black stars mark the onset of higher fire activity; gray star indicates fires of unknown age but interpreted as Early Holocene. P-E 1/4 effective moisture; [ $1 / 4$ high or increase; Y $1 / 4$ low or decrease; - 1/4 savanna/forest mosaic with Y P-E; _ 1/4 shrubby savanna, with [ P-E. Gray zone: Younger Dryas chronozone 


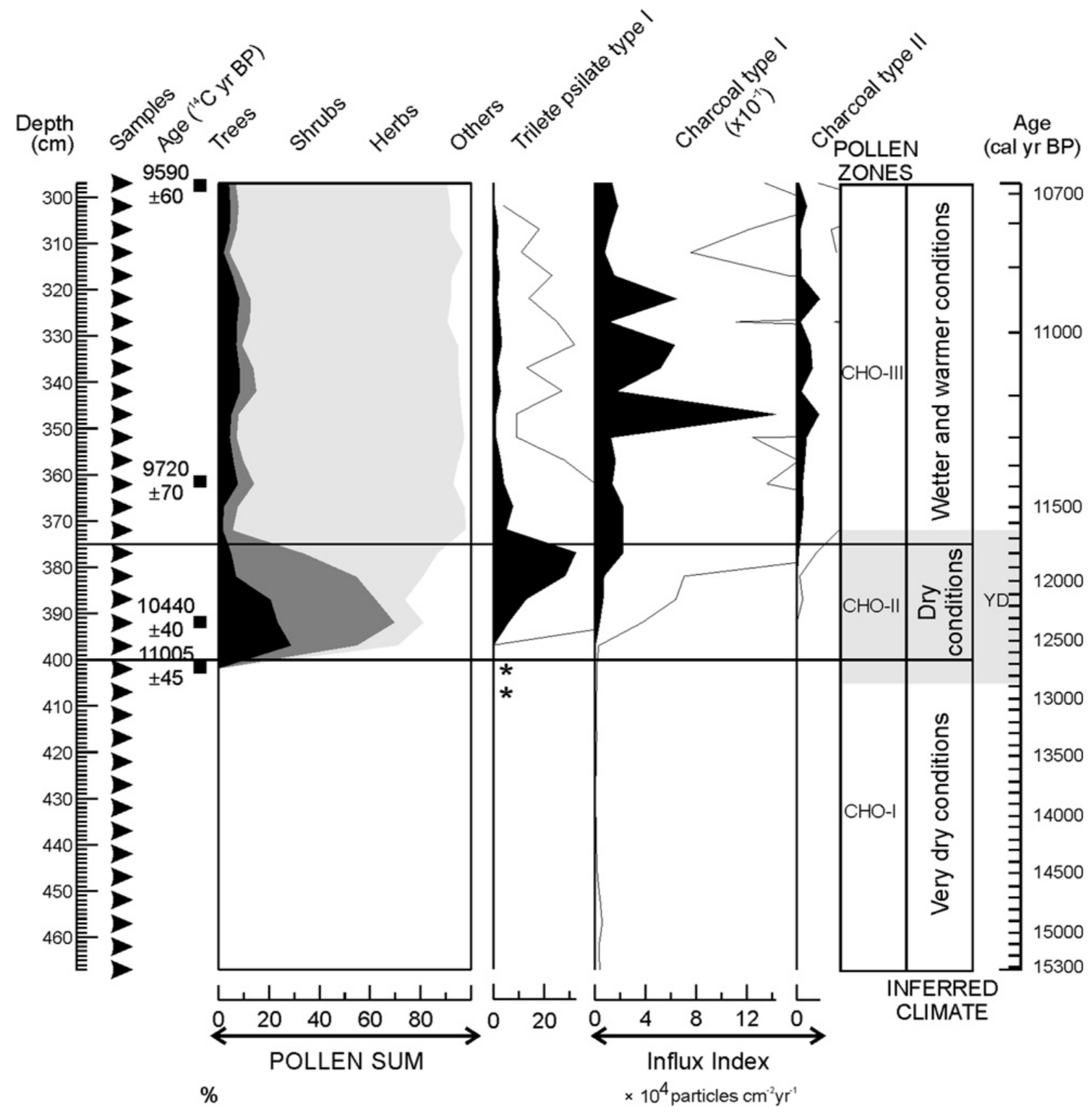

Fig. 4. Summary diagram of Lateglacial interval at Lake Chonita, with charcoal record and the related proxies. Solid lines represent _10 exaggeration. Timescale has been done according to the age-depth model obtained for the equence (See the age-depth model in Supplementary Information: S1). YD: Younger Dryas chronozone (After Montoya et al. (2011a)). 



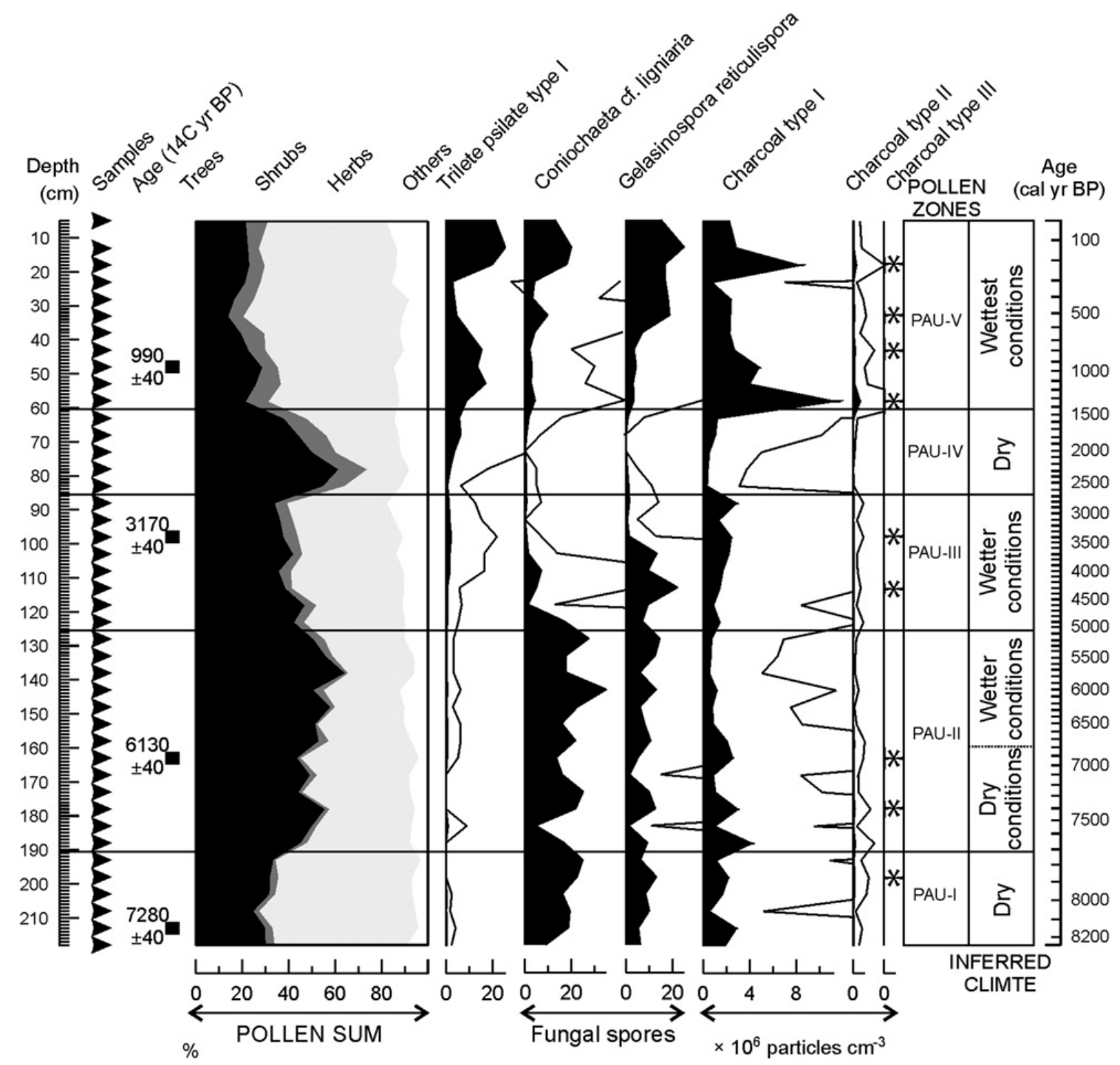

Fig. 6. Summary diagram of El Paují peat bog, with charcoal record and the related proxies. Solid lines represent_10 exaggeration. Timescale has been done according to the agedepth model obtained for the sequence (Supplementary Information: S3). (After Montoya et al. (2011c)). 


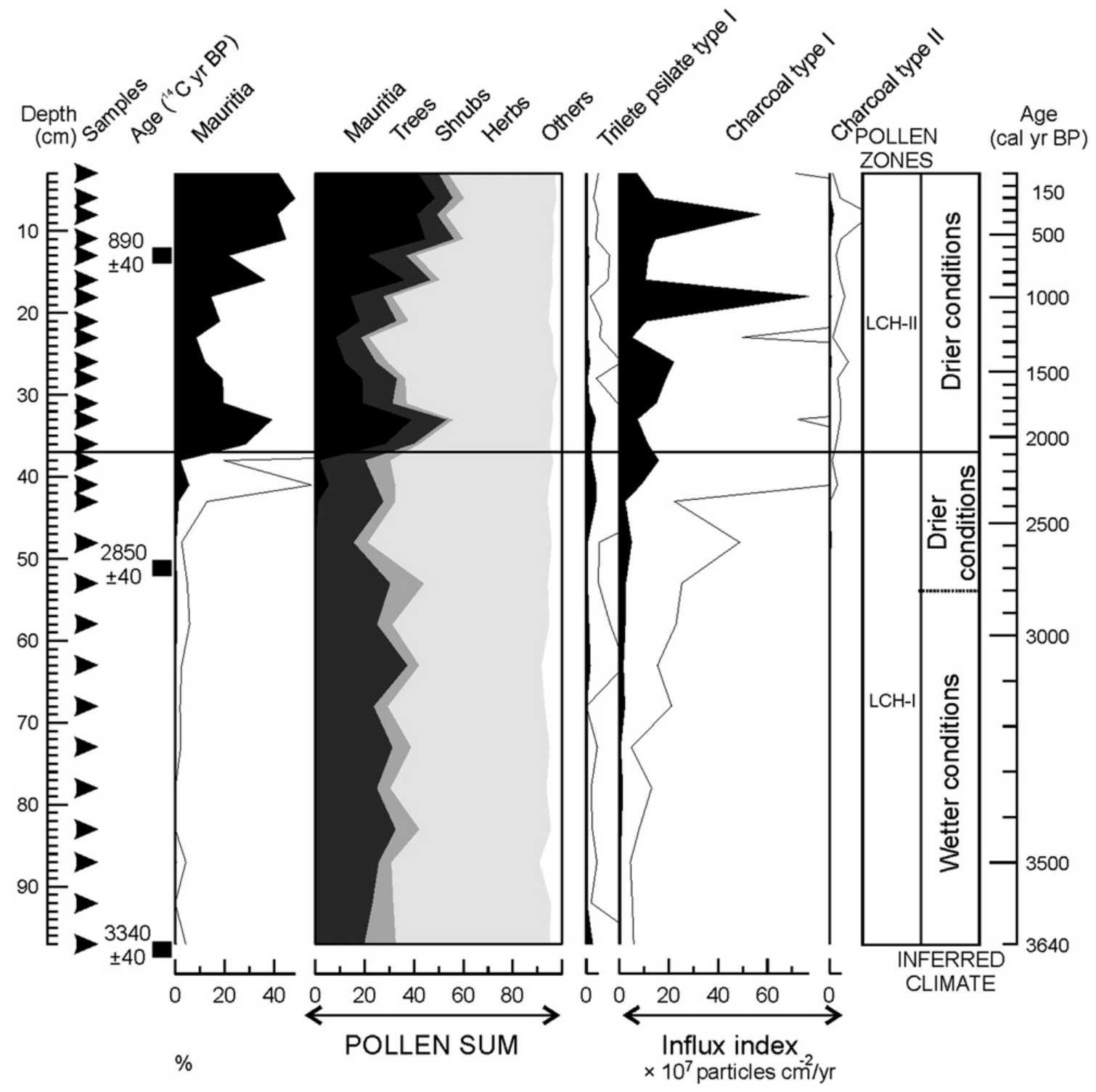

Fig. 7. Summary diagram of last millennia at Lake Chonita, with charcoal record and the related proxies. Solid lines represent 10 exaggeration. Timescale has been done according to the age-depth model obtained for the sequence (Supplementary Information: S1). (After Montoya et al. (2011b)). 


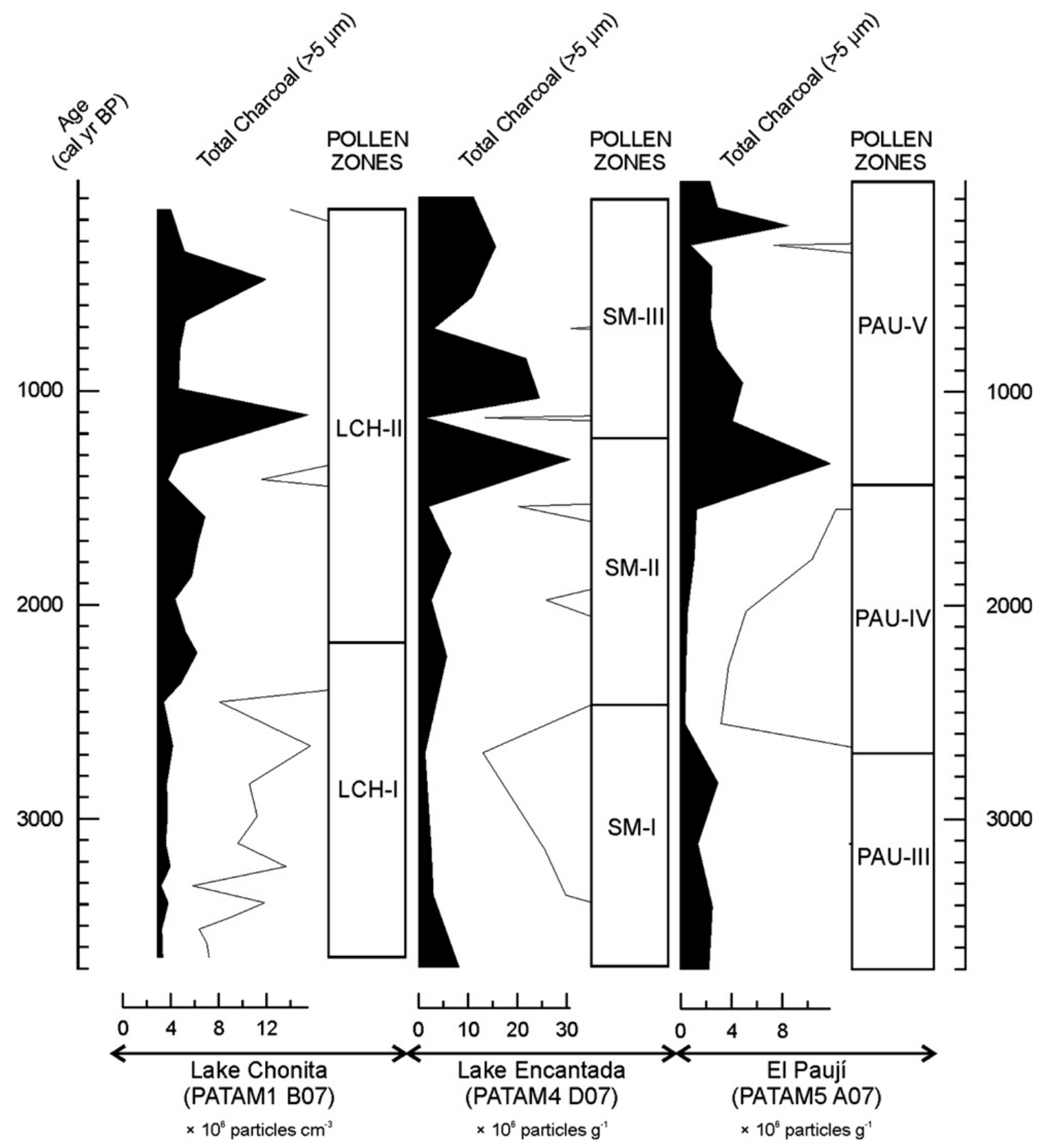

Fig. 8. Total charcoal influx of the three GS sequences analyzed spanning the last three millennia. Solid lines represent_10 exaggeration. 


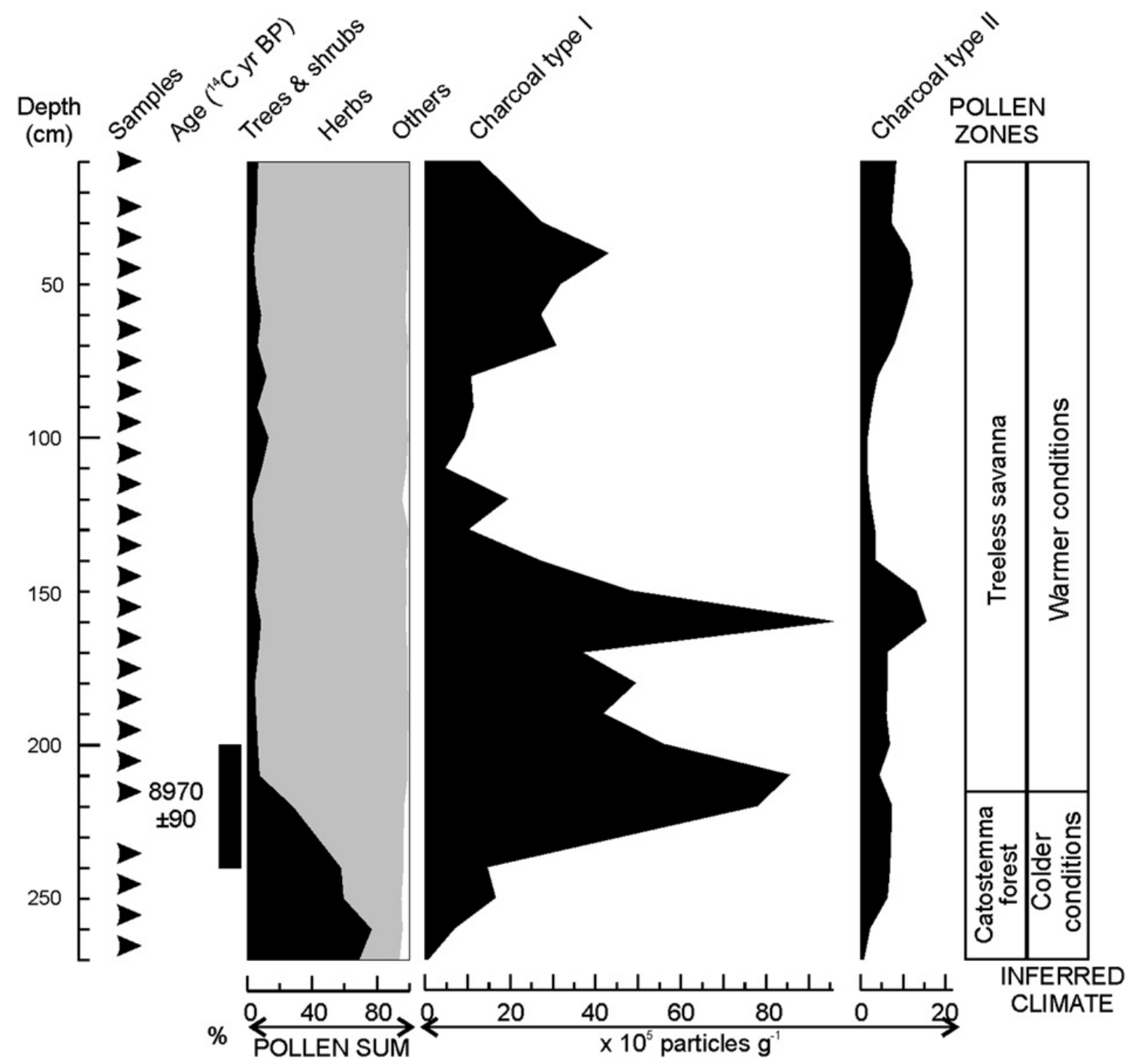

Fig. 9. Summary pollen diagram of Mapaurí and its charcoal record. Pollen zones are referred to the dominant vegetation found, following the diagram description of previous articles. Timescale is not included in this diagram due to the existence of only one radiocarbon dating. (Redrawn from Rull (2009a)). 


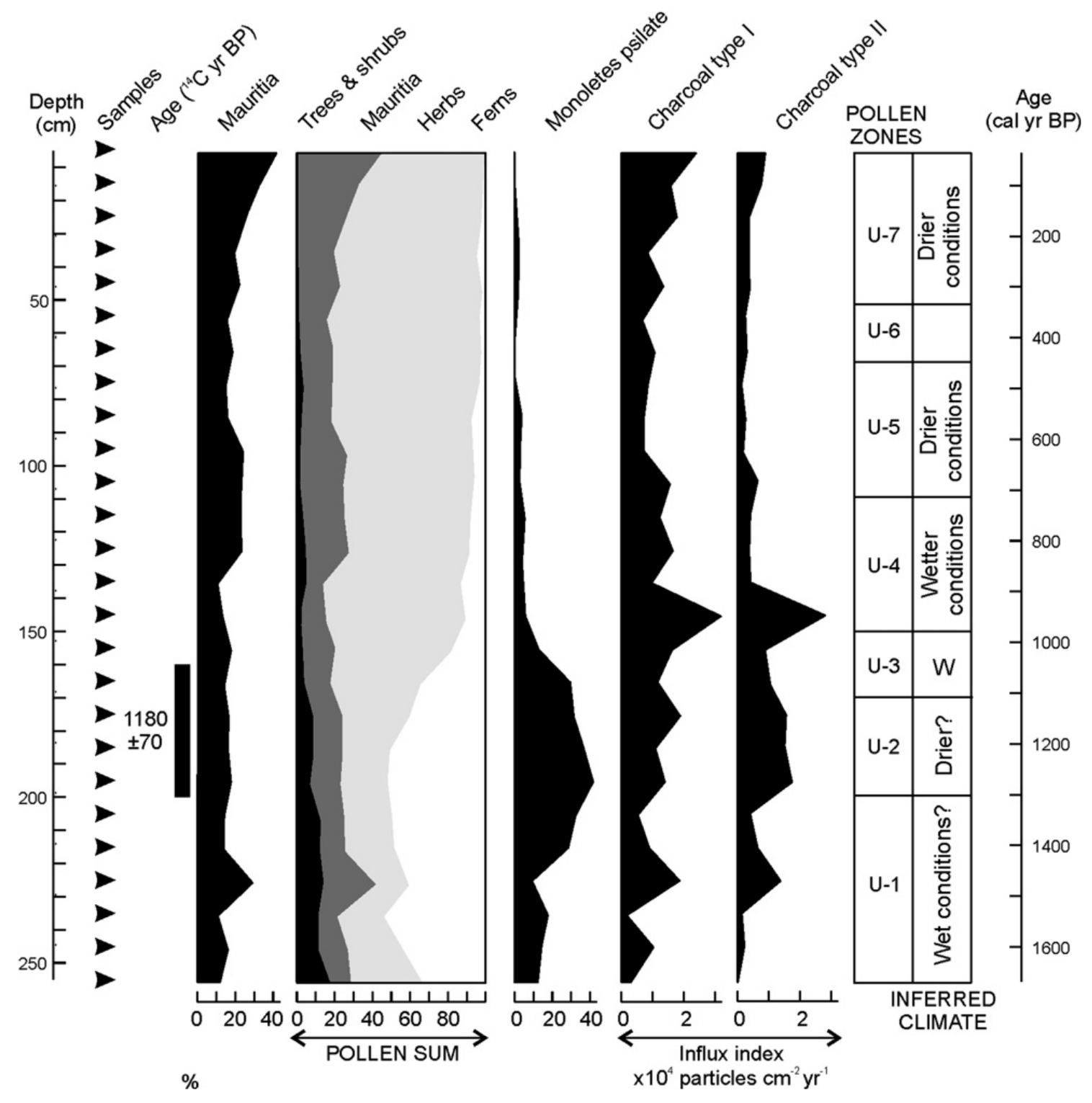

Fig. 10. Summary pollen diagram of Urué and its charcoal record. Timescale has been built according to the original age-depth model obtained for the sequence.W:Wet conditions. (Redrawn from Rull (1999)). 